\title{
The protective effect of Montelukast against skeletal muscle ischemia reperfusion injury: An experimental rat model
}

\author{
Mehmet İlker Bilgiç, M.D., ${ }^{1}$ Güray Altun, M.D., ${ }^{2}$ Hüsamettin Çakıcı, M.D., ${ }^{3}$ \\ Kaan Gideroğlu, M.D., ${ }^{4}$ Gürsel Saka, M.D. ${ }^{2}$
}

\author{
${ }^{1}$ Department of Plastic, Reconstructive and Aesthetic Surgery, Çağıner Hospital, İstanbul-Turkey \\ ${ }^{2}$ Department of Orthopedics and Traumatology, Ümraniye Training and Research Hospital, İstanbul-Turkey \\ ${ }^{3}$ Department of Orthopedics and Traumatology, Abant Bolu İzet Baysal University Faculty of Medicine, Bolu-Turkey \\ ${ }^{4}$ Department of Plastic, Reconstructive and Aesthetic Surgery, İstanbul Kartal Dr. Lütfi Kırdar Training and Research Hospital, İstanbul-Turkey
}

\begin{abstract}
BACKGROUND: Montelukast is a selective leukotriene D-4 receptor antagonist, which specifically and reversibly inhibits cysteinyl leukotriene-I receptor. The aim of this study was to investigate the protective effect of Montelukast on skeletal muscle reperfusion injury created as acute ischemia-reperfusion (IR) injury in Wistar-albino rats.
\end{abstract}

METHODS: The study comprised 16 male Wistar-albino rats. The rats were randomly separated into two groups as control (IR) and treatment (IR+Montelukast). Ischemia was obtained using a femoral artery clamp. After reperfusion following a 2-hour ischemia, muscle samples were taken for biochemical and histopathological analyses.

RESULTS: Malondialdehyde levels were determined to be at statistically higher levels in the control compared with that in the Montelukast group $(p=0.002, p<0.01)$. The superoxide dismutase levels were determined to be at statistically higher level in the Montelukast group compared with that in the control group $(p=0.00 \mathrm{I}, \mathrm{p}<0.0 \mathrm{I})$. In the histopathological examination of the ischemic muscles, edema, polymorinfiltration and erythrocyte extravasation levels were found to be statistically significant higher in the control group than in the Montelukast group. Edema, polymorphonuclear infiltration, and erythrocyte extravasation levels were observed to be significantly reduced in the treatment group compared with that in the control.

CONCLUSION: In this model of skeletal muscle acute IR injury, the protective effect of Montelukast against skeletal muscle reperfusion injury was emphasized. We concluded that Montelukast could accelerate functional recovery in the extremity by limiting the local and systemic complications caused by reperfusion in cases such as extremity trauma with vascular injuries and extremity surgery with prolonged tourniquet application. However, further experimental and clinical studies are required to confirm this effect.

Keywords: Ischemia; Montelukast; reperfusion; skeletal muscle.

\section{INTRODUCTION}

Ischemia-reperfusion (IR) is a iatrogenically created process by the use of a tourniquet, and is often used in extremity surgery. When tissue is exposed to ischemia, a series of chemical events occur in the basal metabolism, progressing as far as functional impairment and necrosis. To be able to provide the appropriate intracellular energy and for the removal of toxic metabolites, the blood circulation of ischemic tissues is crucial.
However, this phenomenon of reperfusion results in a series of metabolic effects paradoxically leading to further damage in the tissue. ${ }^{[1-4]}$ With the expression of several vasoactive mediators, cytokines, endothelin and free toxic oxygen radicals in the reperfused tissue, leukocyte activation, endothelial dysfunction and tissue edema occur. Although several mediators associated with IR have been determined to play a role in local tissue and distant organ dysfunction, leukotrienes (LT) and free toxic oxygen radicals are known to play a crucial role in this process. ${ }^{[5]}$

Cite this article as: Bilgiç Mİ, Altun G, Çakıcı H, Gideroğlu K, Saka G. The protective effect of Montelukast against skeletal muscle ischemia reperfusion injury: an experimental rat model. Ulus Travma Acil Cerrahi Derg 2018;24:185-190.

Address for correspondence: Mehmet ilker Bilgiç, M.D.

Özel Çağıner Hastanesi, Plastik ve Rekonstrüktif Cerrahi, Yıldız Mh., Mirim Çelebi Sk., No: I, Kadıköy, İstanbul, Turkey

Tel: +90 216 - 4284800 E-mail: ilkerbilg@yahoo.com

Ulus Travma Acil Cerrahi Derg 2018;24(3):185-190 DOI: 10.5505/tjtes.2017.22208 Submitted: 22.10.2016 Accepted: 10.1I.2017 Online: 08.05.2018

Copyright 2018 Turkish Association of Trauma and Emergency Surgery 
Montelukast has been shown to be a strong, selective antagonist of cysteinyl leukotriene receptor I (CystLTI) and an antioxidant that is used as an anti-asthmatic drug in a clinical setting. Montelukast prevents leukocyte adhesion and degranulation by inhibiting LTD4 on cysteinyl leukotriene receptors. It has been reported that it protects the kidney and bladder from ischemia/reperfusion damage, and that this molecule is beneficial in ethanol-induced mucosa injury, multi-organ failure due to sepsis, colitis, and testis torsion. ${ }^{[5-9]}$ In addition, the use of various pharmacological and immunological agents has been suggested to decrease or avoid reperfusion injury. However, there has been no appropriately designed study regarding the effect of Montelukast on tourniquet use models.

The aim of this experimental study was to investigate the protective effect of Montelukast on skeletal muscle reperfusion injury in a model of lower extremity skeletal muscle acute IR injury. Therefore, the muscle tissue of rats which were administered Montelukast following IR was compared with that of a control group by measurements taken of malondialdehyde (MDA), which is an indicator of oxidative stress, superoxide dismutase (SOD) levels in the tissue, and histopathological examination.

\section{MATERIALS AND METHODS}

Approval for this experimental study was granted by the Local Ethics Committee. A total of 16 male Wistar-albino rats were used, each weighing 200-250 g. Before the experiment, the rats were kept in wire cages in a 12-hour light-dark cycle at a temperature of $24^{\circ} \mathrm{C}-26^{\circ} \mathrm{C}$ and humidity of $50 \%-60 \%$. At 12 hours before the experiment, nutrition, but not water, was stopped. The care of the rats was applied in accordance with the Laboratory Animals Care and Use guidelines pub- lished by the National Health Institute and prepared by the Laboratory Animal Resource Institute, and the Experimental Animal Care Principles defined by the Medical Research National Association. The muscle tissue samples taken were stored in 10\% formaldehyde for histopathological examination and at $-80^{\circ} \mathrm{C}$ for biochemical examination.

\section{Study Protocol}

All the rats used in the study were acclimatized to the same laboratory environment for one week before the study. They were given standard laboratory food and water, and food but not water was terminated at 12 hours before the operations. Anesthesia was administered to all the rats as an intraperitoneal mixture of $30 \mathrm{mg} / \mathrm{kg}$ ketamine HCL (Ketalar flacon, Pfizer, Istanbul, Turkey) and $25 \mathrm{mg} / \mathrm{kg}$ Chlorpromazine (Largactil ampoule, Eczacıbaşı, Istanbul, Turkey) and was maintained as required without changing the dosage table. Oxygen support was provided to all the rats with a mask at $3 \mathrm{~L} / \mathrm{min}$ and heart rate was monitored and recorded at 30-min intervals.

Under a heating lamp, the rats were placed in a supine position and both lower extremities were shaved from below the abdomen. The rats were randomly separated into two groups of eight animals, defined as the control (C) and the treatment $(T)$ groups. The animals in the control group were intraperitoneally injected with I $\mathrm{mL}$ saline 30 mins before the intervention. At the same time, the subjects in the treatment group were intraperitoneally injected $10 \mathrm{mg} / \mathrm{kg}$ Montelukast and the all doses were completed to I $\mathrm{mL}$ with saline solution. At 30 mins after the injection, the skin of the left lower extremity of each rat was cleaned with Betadine (10\% povidone iodine solution). The inguinal canal was opened with a 2-cm incision exactly over the inguinal ligament (Fig. Ia).
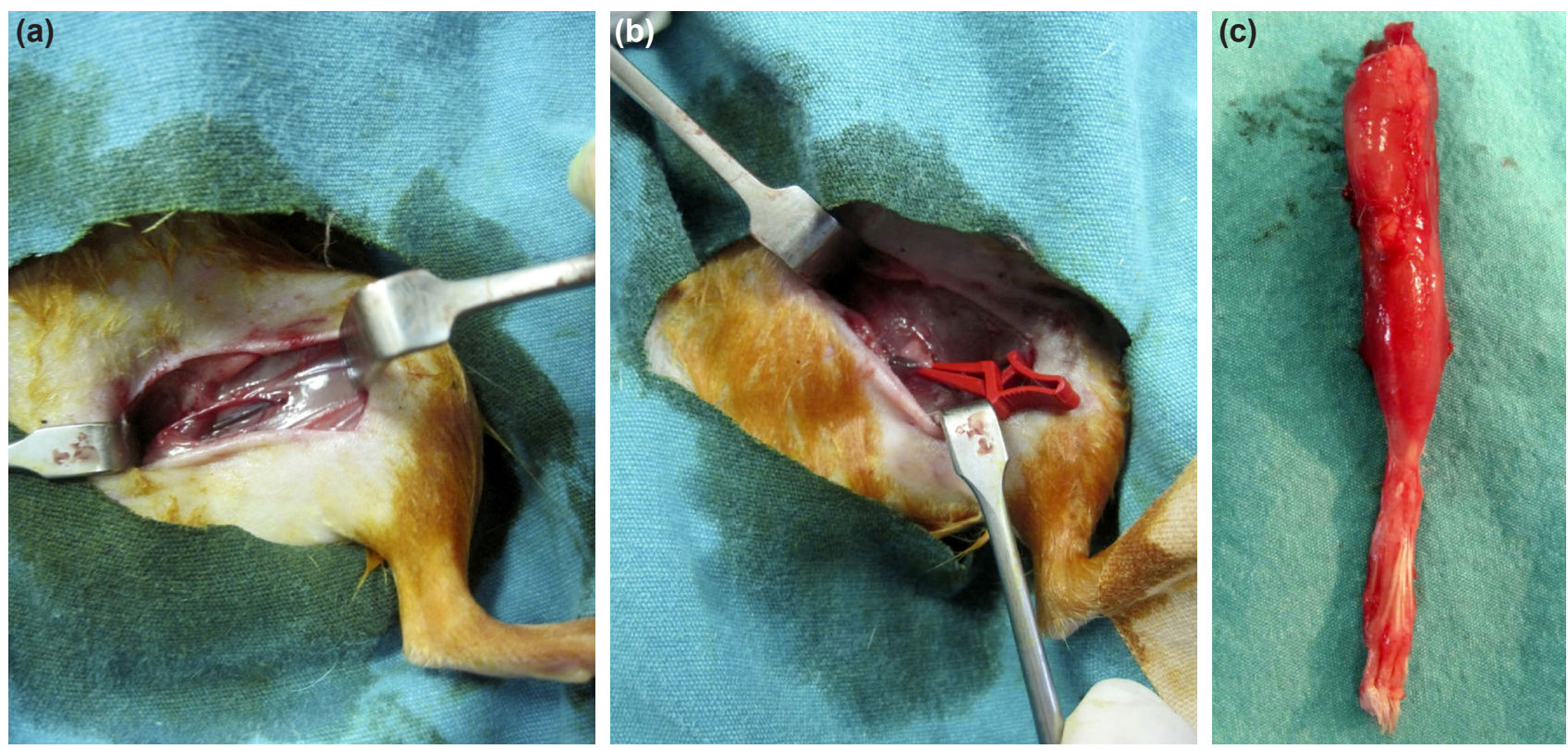

Figure 1. (a) Inguinal canal exploration and exposing of femoral artery and vein. (b) Clamping of femoral vessels (Vascu-Statt ${ }^{\circledR}$ mini clamp Scanlan Surgical Equipments, Minnesota, USA). (c) Skin completely stripped off from the extremity. 
Table I. Light microscope results

\begin{tabular}{lccrr}
\hline Group & Edema & PMNL infiltration & Erythrocyte extravasation & Necrosis \\
\hline Ischemia-reperfusion (control) $(\mathrm{n}=8)$ & $2,2,3,2,2,3,2,2$ & $3,2, I, 2,2,2,2,2$ & $2,2,3,3,3,2,2,3$ & $0,0,0,0,0,0,0,0$ \\
Treatment $(\mathrm{n}=8)$ & $\mathrm{I}, \mathrm{I}, 2, \mathrm{I}, \mathrm{I}, 2, \mathrm{I}, 2$ & $\mathrm{I}, 2, \mathrm{I}, \mathrm{I}, 2, \mathrm{I}, \mathrm{I}, \mathrm{I}$ & $2,2, \mathrm{I}, \mathrm{I}, \mathrm{I}, 2, \mathrm{I}, 2$ & $0,0,0,0,0,0,0,0$ \\
\hline PMNL: Polymorphonuclear leukocytes. & & & &
\end{tabular}

The femoral artery and vein were explored. The extremity was emptied by wrapping an Esmarch bandage around the extremity from distal to proximal. By placing a clamp on the femoral artery and vein, circulation was stopped and ischemia was achieved (Fig. Ib). After perfusion following a 2-hour period of ischemia, the left lower extremity was disarticulated from the acetabulum in all rats. The skin was completely stripped off (Fig. Ic). The muscle tissues of the lower extremities were separated into a total of eight groups for biochemical and histopathological examination, as paired samples from the control and treatment groups and the samples were sent under appropriate conditions for evaluation. At the end of the experiment, all the animals were sacrificed by high-dose anesthesia.

\section{Histopathological Analyses}

The muscle samples of the groups were fixed in 10\% formaldehyde then passed through a series of graded alcohol and then paraffin blocks were prepared. Slices $5 \mu \mathrm{m}$ in thickness were cut and examined by staining with hematoxylin eosin. For each subject, a series of five tissue slices were taken and these were evaluated and scored for edema, PMNL cell infiltration and erythrocyte extravasation. Evaluation was made at $\times 40$ microscope magnification and scoring was accepted as $0=$ normal, $\mathrm{I}=$ mild effect, $2=$ moderate effect, and $3=$ severe effect (Table I). ${ }^{[10]}$

\section{Biochemical Analyses \\ Malondialdehyde Level Measurement}

MDA measurement is the most frequently used test for determining the level of lipid peroxidation and oxidant damage. Each tissue sample was prepared for homogenization by adding a I/IO I.I5 M KCL buffer. The tissue protein content was determined using the Biuret method; $0.2 \mathrm{~mL}$ of $8.1 \%$ sodium dodecyl sulfate, $1.5 \mathrm{~mL}$ of $3.5 \mathrm{pH} 20 \%$ acetic acid, and $1.5 \mathrm{~mL} 0.8 \%$ thiobarbituric acid (TBA) solution were added to $0.4 \mathrm{~mL}$ homogenate, mixed and heated to $95^{\circ} \mathrm{C}$ for 60 mins. After cooling, $5 \mathrm{~mL}$-Butanol/pyridine ( $15 \mathrm{l}$; v/v) was added. The absorbency of the top layer at $532 \mathrm{~nm}$ was measured by centrifugation at $4000 \mathrm{rpm}$ for 10 mins. Using standard I, I,3,3-tetraethoxypropane, the calculated MDA levels were stated as nmol/g protein (Table 2).

\section{Determining Tissue SOD Activity}

SOD activity was measured with the technique on the basis of the inhibition by SOD of the reduction of nitroblue tetra-
Table 2. Tissue malondialdehyde levels

\begin{tabular}{cc}
\hline \multicolumn{2}{c}{ Malondialdehyde level (nmol/g protein) } \\
\hline $\begin{array}{c}\text { Ischaemia-reperfusion } \\
\text { (Control Group) }\end{array}$ & $\begin{array}{c}\text { Ischaemia-reperfusion+Montelukast } \\
\text { (Treatment Group) }\end{array}$ \\
\hline 37.96 & 26.10 \\
46.58 & 28.97 \\
44.04 & 37.96 \\
47.02 & 26.99 \\
48.48 & 30.25 \\
46.95 & 32.24 \\
48.02 & 44.40 \\
48.54 & 31.02 \\
\hline
\end{tabular}

zolium of superoxide formed in the reaction of photoreduced riboflavin and oxygen.

The tissue samples were homogenized with a $7.8 \mathrm{pH}$ buffer of I/I0 0.05 M KPO4. The tissue protein content was measured with the Biuret method. $0.2 \mathrm{~mL}$ of $0.1 \mathrm{M}$ EDTA containing $1.5 \mathrm{mg} \mathrm{NaCN}$ of $100 \mathrm{~mL}$, and $0.1 \mathrm{~mL}$ of $1.5 \mathrm{mM}$ NBT were added to $0.05 \mathrm{~mL}$ homogenate. The total volume of the tube was completed to $3 \mathrm{~mL}$ with phosphate buffer and the tubes were heated to $20^{\circ} \mathrm{C}-22^{\circ} \mathrm{C}$. To all the tubes, $0.5 \mathrm{~mL} 0.12$ $\mathrm{mM}$ riboflavin was added and they were then placed in an illumination box, $60 \times 15 \times 20 \mathrm{~cm}$ in size, with $15 \mathrm{~W}$ uniform fluorescent lighting. After waiting for 15 mins, using the tube where no homogenate was placed as a blind, the absorbency at $532 \mathrm{~nm}$ was measured. By tracing the given SOD standard inhibition on the graph, the SOD activity of the samples was determined. By defining one SOD unit as the amount of enzyme providing half the maximum inhibition of NBT reduction, the enzyme activity in tissues was stated as U/mg protein (Table 3).

\section{Statistical Analyses}

In the evaluation of the findings obtained in the study, all statistical analyses were made using IBM SPSS Statistics 22 software (IBM, SPSS, TR). The conformity of the data of the parameters to normal distribution was evaluated using the Shapiro-Wilks test. In the comparison between two groups of parameters not showing normal distribution, the MannWhitney $U$ test was used. Values were stated as mean \pm 
Table 3. Tissue superoxide dismutase activity

Superoxide dismutase activity (U/mg protein)

\begin{tabular}{cc}
\hline $\begin{array}{c}\text { Ischaemia-reperfusion } \\
\text { (Control Group) }\end{array}$ & $\begin{array}{c}\text { Ischaemia-reperfusion+Montelukast } \\
\text { (Treatment Group) }\end{array}$ \\
\hline 10.80 & 29.20 \\
17.70 & 19.50 \\
15.60 & 17.50 \\
11.70 & 26.70 \\
11.00 & 20.10 \\
12.20 & 18.10 \\
14.70 & 14.20 \\
11.00 & 20.10 \\
\hline
\end{tabular}

standard deviation (SD). A value of $\mathrm{p}<0.05$ was accepted as statistically significant.

\section{RESULTS}

The MDA levels were determined to be at a statistically higher level in the control group compared with the Montelukast group $(p=0.002, p<0.01)$. The SOD levels were determined to be at a statistically higher level in the Montelukast group compared with the control group $(p=0.00 \mathrm{I}$, $\mathrm{p}<0.0 \mathrm{I}$ ) (Table 4). Edema, PMNL infiltration and erythrocyte extravasation levels were found to be statistically significant higher in the control group than in the treatment group (Table 5).

In the control group, increased connective tissue cells and neutrophils were determined between the muscle fibers. Ev- ident edema and erythrocyte extravasation were observed across the width of the muscle section in this group. No necrosis or nuclear centralization was determined in the muscle cells. In the treatment group, edema, PMNL infiltration and erythrocyte extravasation levels were observed to be reduced to a statistically significant level compared with that of the control group.

\section{DISCUSSION}

When blood circulation to the tissues is interrupted as a result of tourniquet application in extremity surgery, a series of biochemical changes occur starting with impaired cell function of that tissue and progressing as far as cell death and finally damage occurs.

Blood circulation insufficiency may occur effect of tourniquet application during prolonged extremity surgery and this causes a series of biochemical reactions in the extremity tissue which may cause cell damage and more.

Neuromuscular damage associated wih tourniquet application, as much as it is related to pressure and tissue deformation, is also closely related to reperfusion damage following ischemia. Skeletal muscle is more resistant to ischemia than other tissues. In orthopedic surgery, prolonged duration of tourniquet application, extremity trauma with artery injuries, reconstructive microsurgery, and acute compartment syndrome are frequently encountered ischemic events. ${ }^{[1,12]}$

The basic aim in ischemic events is to prevent muscle necrosis by providing early reperfusion. In addition, reperfusion itself, known as "reperfusion injury," leads to a pathophysiological condition. ${ }^{\left[{ }^{\prime \prime}\right]}$ Tissue damage following ischemia mostly occurs

Table 4. Evaluation of the malondialdehyde and superoxide dismutase levels of the groups

\begin{tabular}{|c|c|c|c|}
\hline & Control & Montelukast & $\mathbf{p}$ \\
\hline & Mean $\pm S D$ (median) & Mean $\pm S D$ (median) & \\
\hline Malondialdehyde (nmol/g protein) & $45.95 \pm 3.53(46.99)$ & $32.24 \pm 6.12(30.64)$ & $0.002^{* *}$ \\
\hline Superoxide dismutase (nmol/mg protein) & $13.09 \pm 2.59(\mid 1.95)$ & $20.68 \pm 4.92(19.8)$ & $0.001^{* *}$ \\
\hline
\end{tabular}

Table 5. Evaluation of edema and superoxide dismutase levels of the groups

\begin{tabular}{|c|c|c|c|c|c|c|c|}
\hline & \multicolumn{3}{|c|}{ Ischemia-reperfusion (control) } & \multicolumn{3}{|c|}{ Treatment } & \multirow[t]{2}{*}{$\mathbf{p}$} \\
\hline & Min-Max & Mean $\pm S D$ & Median & Min-Max & Mean $\pm S D$ & Median & \\
\hline Edema & $2-3$ & $2.25 \pm 0.46$ & 2 & $\mathrm{I}-2$ & $1.38 \pm 0.52$ & 1 & $0.007^{* *}$ \\
\hline PMNL infiltration & $1-3$ & $2 \pm 0.53$ & 2 & $\mathrm{I}-2$ & $1.25 \pm 0.46$ & 1 & $0.013^{*}$ \\
\hline Erythrocyte extravasation & $2-3$ & $2.5 \pm 0.53$ & 2.5 & $1-2$ & $1.5 \pm 0.53$ & 1.5 & $0.006^{* *}$ \\
\hline
\end{tabular}

Mann-Whitney U Test. " $\mathrm{p}<0.05 ;{ }^{* *} \mathrm{p}<0.0$ I. PMNL: Polymorphonuclear leukocytes; SD: Standard deviation. 
during reperfusion. ${ }^{[13]}$ Reperfusion damage occurs through a complex mechanism of free oxygen radicals, endothelial factors, and neutrophils together. It is believed that the primary trigger of the damage is damage to the endothelial cells. ${ }^{[1-16]}$ Numerous substances and biochemical reactions have been determined to directly or indirectly contribute to reperfusion damage. As a result of the interaction between these substances, free oxygen radicals emerge, which are partial mediators of reperfusion in IR damage.

Although the results obtained in this study have shown a protective effect of Montelukast on skeletal muscle, there were some limitations. These include the relatively small number of subjects, different biochemical parameters that have not been measured, such as lactate dehydrogenase, creatine kinase, and the apoptosis of the post-reperfusion tissues, no assessment being made of the effects of the application of Montelukast at different doses and periods of ischemia.

There have been studies in literature on the use of several agent substances to prevent the formation of tissue damage following reperfusion. ${ }^{[6,15,17,18]}$ One of these substances is Montelukast, a strong and specific LTD4 receptor antagonist, which was used in this study. Montelukast was used in this experimental study as it was appropriate to the aims of the study, successful results have been obtained in the experiments of IR in different tissues and it is currently safely used in asthma treatment. A specific aspect of this study was that to the best of our knowledge there has not been any study published in literature associated with the effect of Montelukast on IR in a skeletal muscle model. Thus, as one of the indicators of free radical damage formed in the IR process, the levels were measured of SOD as an enzymatic antioxidant, and malondialdehyde (MDA ). The levels of SOD and MDA are the biochemical indicators of free radical damage formed in the IR process.MDA is a product of cell membrane lipid peroxidation and the measurement of this indicates the amount of free radical formation. ${ }^{[19]}$ SOD is an enzymatic antioxidant which catalyses the reaction changing superoxide to hydrogen peroxide and molecular oxygen and is an endogenous metalloenzyme protecting tissues against free radicals, especially 02 . This reaction is known as "the first defense against oxidative stress," because superoxide is a strong initiator of the radical chain reactions. The $\mathrm{O} 2$ levels in the cellular compartment are kept under control through this system. ${ }^{[20]}$

In the present experimental study, when the MDA levels were examined as an indicator of skeletal muscle reperfusion damage, the MDA levels of the control group were found to be statistically significantly higher than those of the Montelukast group $(p=0.002, p<0.01)$ (Table I). This shows that Montelukast has an effect of reducing free radicals (Table 3 ). In the control group of this study, edema, PMNL infiltration, and erythrocyte extravasation levels were determined to be statistically significantly higher than those of the treatment group (Table 2). This supports the protective effect of Montelukast against reperfusion damage formed in the muscle tissue after IR.

In studies of IR, antioxidant enzyme activity has been seen to fall following reperfusion, which has been associated with the increased use of these enzymes because of increasing oxidative stress. ${ }^{[21,22]}$ In the present study, a reduction was determined in the activity of SOD antioxidant enzymes in the control group and an increase was determined in SOD enzyme activities in the treatment group. This finding supports IR studies in literature in general. However, in contrast, in a skeletal muscle IR study by Ozyurt et al., ${ }^{[18]}$ the SOD and Catalase (CAT) antioxidant enzyme activity levels were found to be high in muscle tissue after reperfusion. This increase has been associated with the over-production of free oxygen radicals in IR events which then stimulates the antioxidant defense system and causes the increase in antioxidant enzyme expressions.

In conclusion, in this experimental study, the expected oxidative damage was determined which was believed to be caused by IR in the lower extremity where a tourniquet was applied. Regarding the treatment efficacy, as the Montelukast administered against skeletal muscle reperfusion injury was found to have prevented cell damage at a significant level in the histological and biochemical examinations, suppressed the formation of MDA, and increased the antioxidant capacity, these findings were seen to be consistent with those of previous studies. It was concluded that with these effects, Montelukast could accelerate functional recovery of the extremity tissue by limiting the local and systemic complications caused by reperfusion. We did not study the effect of Montelukast on $\mathrm{I}-\mathrm{R}$ injury at different doses or different administration times. Additional studies are required for examining these factors on the effect of Montelukast. However, there still remains a requirement for further extensive experimental and clinical studies to be able to use Montelukast in clinical applications against IR damage. Montelukast has a protective effect against $\mathrm{I} / \mathrm{R}$ injury in skeletal muscle and may reduce the incidence of compartment syndrome, especially after acute or chronic peripheral arterial occlusion.

\section{Conclusions}

In this experimental study, the protective effect of Montelukast on skeletal muscle reperfusion injury was investigated. It was concluded that Montelukast could accelerate recovery by limiting the complications caused by reperfusion in cases where tissue ischemia has formed, such as extremity traumas with acute vascular injuries, prolonged tourniquet application in extremity surgery. However, there is a need for further experimental and clinical studies to support and confirm these findings.

Conflict of interest: None declared. 


\section{REFERENCES}

1. Kuzu MA, Köksoy C, Kale IT, Tanik A, Terzi C, Elhan AH. Reperfusion injury delays healing of intestinal anastomosis in a rat. Am J of Surgery 1998;76:348-51. [CrossRef]

2. Grace PA. Ischaemia-reperfusion injury. British J of Surgery 1994;81:637-47. [CrossRef]

3. Zimmerman BJ, Granger DN. Reperfusion injury. Surg Clin North Am 1992;72:65-83. [CrossRef]

4. Maxwell SR, Lip GY. Reperfusion injury: a review of the pathophysiology, clinical manifestations and therapeutic options. Int J Cardiol 1997;58:95-117. [CrossRef]

5. Ozkan E, Yardimci S, Dulundu E, Topaloğlu U, Sehirli O, Ercan F, et al. Protective potential of montelukast against hepatic ischemia/reperfusion injury in rats. J Surg Res 2010;159:588-94. [CrossRef]

6. Ozturk H, Ozturk H, Gideroglu K, Terzi H, Bugdayci G. Montelukast protects against testes ischemia/reperfusion injury in rats. Can Urol Assoc J 2010;4:174-9. [CrossRef]

7. Sener G, Sehirli O, Velioğlu-Oğünç A, Cetinel S, Gedik N, Caner M, et al. Montelukast protects against renal ischemia/reperfusion injury in rats. Pharmacol Res 2006;54:65-71. [CrossRef]

8. Sener G, Sehirli O, Toklu H, Ercan F, Alican I. Montelukast reduces ischaemia/reperfusion-induced bladder dysfunction and oxidant damage in the rat. J Pharm Pharmacol 2007;59:837-42. [CrossRef]

9. Sılay MS, Toklu H, Özağarı A, Aydın M, Tetik Ş, Şener G, et al. Montelukast prevents testes against ischemia-reperfusion injury through suppression of iNOS expression. Turk J Urol 2014;40:221-7. [CrossRef]

10. Erdem M, Bostan B, Güneş T, Özkan F, Sen C, Özyurt H, et al. Protective effects of melatonin on ischemia-reperfusion injury of skeletal muscle [Article in Turkish]. Eklem Hastalik Cerrahisi 2010;21:166-71.

11. Klenerman L, Biswas M, Hulands GH, Rhodes AM. Systemic and local effects of the application of a tourniquet. J Bone Joint Surg Br
1980;62:385-8. [CrossRef]

12. Wang WZ, Fang XH, Stephenson LL, Baynosa RC, Khiabani KT, Zamboni WA. Microcirculatory effects of melatonin in rat skeletal muscle after prolonged ischemia. J Pineal Res 2005;39:57-65. [CrossRef]

13. Toledo-Pereyra LH, Lopez-Neblina F, Toledo AH. Reactive oxygen species and molecular biology of ischemia/reperfusion. Ann Transplant 2004;9:81-3.

14. Semenza GL. Cellular and molecular dissection of reperfusion injury: ROS within and without. Circ Res 2000;86:117-8. [CrossRef]

15. Terzi C, Kuzu A, Tanık A, Kale T, Aşlar K, Elhan A. Sıçanlarda iskemi modelinde proflaktik kısa ve uzun süreli yüksek doz allopurinol kullanımının mortaliteye etkisi. Klin Den Cerr Derg 2000:8:10-6.

16. Bathe OF, Chow AW, Phang PT. Splanchnic origin of cytokines in a porcine model of mesenteric ischemia-reperfusion. Surgery 1998;123:79-88. [CrossRef]

17. Erkanli K, Kayalar N, Erkanli G, Ercan F, Sener G, Kirali K. Melatonin protects against ischemia/reperfusion injury in skeletal muscle. J Pineal Res 2005;39:238-42. [CrossRef]

18. Ozyurt H, Ozyurt B, Koca K, Ozgocmen S. Caffeic acid phenethyl ester (CAPE) protects rat skeletal muscle against ischemia-reperfusion-induced oxidative stress. Vascul Pharmacol 2007;47:108-12. [CrossRef]

19. Petrasek PF, Homer-Vanniasinkam S, Walker PM. Determinants of ischemic injury to skeletal muscle. J Vasc Surg 1994;19:623-31. [CrossRef]

20. Guemouri L, Artur Y, Herbeth B, Jeandel C, Cuny G, Siest G. Biological variability of superoxide dismutase, glutathione peroxidase, and catalase in blood. Clin Chem 1991;37:1932-7.

21. Okatani Y, Wakatsuki A, Reiter RJ, Enzan H, Miyahara Y. Protective effect of melatonin against mitochondrial injury induced by ischemia and reperfusion of rat liver. Eur J Pharmacol 2003;469:145-52. [CrossRef]

22. Sener G, Sehirli AO, Keyer-Uysal M, Arbak S, Ersoy Y, Yeğen BC. The protective effect of melatonin on renal ischemia-reperfusion injury in the rat. J Pineal Res 2002;32:120-6. [CrossRef]

\section{DENEYSEL ÇALIŞMA - ÖZET}

\section{İskelet kasında iskemi-reperfüzyon yaralanmasına karşı Montelukastın koruyucu etkisi: Sıçanlarda deneysel çalışma}

\section{Dr. Mehmet İlker Bilgiç, ${ }^{1}$ Dr. Güray Altun, ${ }^{2}$ Dr. Hüsamettin Çakıcı, ${ }^{3}$ Dr. Kaan Gideroğlu, ${ }^{4}$ Dr. Gürsel Saka ${ }^{2}$}

${ }^{1}$ Özel Çağıner Hastanesi, Plastik ve Rekonstrüktif Cerrahi Kliniği, İstanbul
${ }^{2}$ Ümraniye Eğitim ve Araştırma Hastanesi, Ortopedi ve Travmatoloji Kliniği, İstanbul
${ }^{3}$ Abant Bolu İzzet Baysal Üniversitesi Tıp Fakültesi, Ortopedi ve Travmatoloji Anabilim Dalı, Bolu
${ }^{4}$ Kartal Dr. Lütfi Kırdar Eğitim ve Araştırma Hastanesi, Plastik ve Rekonstrütif Cerrahi Kliniği, İstanbul

AMAÇ: Montelukast, sisteinil lökotrien-I reseptörünü spesifik ve geri dönüşümlü olarak inhibe eden, selektif bir lökotrien D-4 reseptör antagonistidir. Bu deneysel çalışmada, akut iskemi/reperfüzyon (I/R) yaralanması oluşturulan Wistar albino türü sıçanlarda montelukastın iskelet kası reperfüzyon yaralanmasına karşı olası koruyucu etkisi araştırıldı.

GEREÇ VE YÖNTEM: Bu çalışmaya 16 erkek Wistar albino türü sıçan alındı. Sıçanlar, rastgele sırasıyla kontrol (I/R) ve çalışma (I/R + Montelukast) olmak üzere iki gruba ayrıldı. Ekstremite iskemisi, femoral artere klemp konarak sağlandı. İki saatlik iskemi süresini takiben iki saat süren reperfüzyon sonrasında, biyokimyasal analiz ve histopatolojik inceleme için kas örnekleri alındı.

BULGULAR: Kontrol grubunun melondialdehit düzeyleri, montelukast grubundan istatistiksel olarak anlamlı düzeyde yüksekti ( $p=0.002$; $p<0.01$ ). Montelukast grubunun süperoksit dismutaz düzeyleri ise kontrol grubundan istatistiksel olarak anlamlı düzeyde yüksek bulundu ( $\mathrm{p}=0.00 \mathrm{I} ; \mathrm{p}<0.0 \mathrm{I}$ ). İskemik kasların histopatolojik incelemesinde iskemi reperfüzyon grubunun ödem, polimorfonükleer lökosit (PMNL) infiltrasyonu ve eritrosit ekstravazasyonu düzeyleri, tedavi grubundan istatistiksel olarak anlamlı düzeyde yüksekti. Tedavi edilen grupta ödem, PMNL infiltrasyonu ve eritrosit ekstravazyonu ise iskemi grubuna göre oldukça azalmış olarak izlendi.

TARTIŞMA: Bu iskelet kası akut I/R yaralanması modelinde; montelukastın iskelet kası reperfüzyon yaralanmasına karşı koruyucu etkisi vurgulandı. Montelukast, akut vasküler yaralanmalı ekstremite travmaları olgularda ve turnike süresi uzamış ekstremite cerrahisinde, reperfüzyonun neden olduğu lokal ve sistemik komplikasyonları sınırlandırarak ekstremitede fonksiyonel iyileşmeyi hızlandırabileceği sonucuna varılmıştır. Ancak yine de bu etkinin yapılacak deneysel ve klinik çalışmalar ile de desteklenmesinin gerekli olduğu kanaatindeyiz.

Anahtar sözcükler: İskelet kası; iskemi; montelukast; reperfüzyon.

Ulus Travma Acil Cerrahi Derg 2018;24(3): I85-190 doi: 10.5505/tjtes.2017.22208 